\title{
Cytokine production and signalling in human THP-1 macrophages is dependent on Toxocara canis glycans
}

\author{
Ewa Długosz ${ }^{1}$ (D) $\cdot$ Katarzyna Basałaj ${ }^{2} \cdot$ Anna Zawistowska-Deniziak $^{2}$
}

Received: 6 February 2019 / Accepted: 19 July 2019 / Published online: 8 August 2019

(C) The Author(s) 2019

\begin{abstract}
The effect of Toxocara canis antigens on cytokine production by human THP-1 macrophages was studied in vitro. Toxocara Excretory-Secretory products (TES) and recombinant mucins (Tc-MUC-2, Tc-MUC-3, Tc-MUC-4, and Tc-MUC-5) as well as deglycosylated forms of these antigens were used in the study. TES products stimulated macrophages to produce the innate proinflammatory IL-1 $\beta$, IL-6, and TNF- $\alpha$ cytokines regardless of the presence of glycans. Recombinant mucins induced glycandependent cytokine production. Sugar moieties led to at least 3-fold higher production of regulatory IL-10 as well as proinflammatory cytokines. The presence of glycans on mucins also affected the downstream signalling pathways in stimulated cells. The most prominent difference was noted in AKT and AMPK kinase activation. AKT phosphorylation was observed in cells stimulated with glycosylated mucins, whereas treatment with deglycosylated antigens led to AMPK phosphorylation. MAP kinase family members such as JNK and p38 and c-Jun transcription factor were phosphorylated in both cases what suggests that toll-like receptor signalling may be involved in mucin-treated macrophages. This pathway is however modified by other signalling molecules as only mucins containing intact sugars significantly induced the production of cytokines.
\end{abstract}

Keywords Toxocara $\cdot$ Antigens $\cdot$ Macrophages $\cdot$ Cytokines $\cdot$ Kinases $\cdot$ Signalling

\section{Introduction}

Toxocara canis and Toxocara cati, the dog and the cat roundworm respectively, are parasitic nematodes with great zoonotic potential. Toxocariasis is prevalent across the globe, with children especially at risk of infection. The incidence of $T$. canis serum-positive individuals varies from $1.6 \%$ in Japan and $2.4 \%$ in Denmark, up to $63 \%$ in Bali, $86 \%$ in Saint-Lucia, and almost 93\% in La Reunion (Magnaval et al. 2001; Ma et al. 2018).

Upon infection of the human host, Toxocara larvae migrate through various tissues leading to different clinical syndromes: visceral larva migrans (VLM), ocular larva migrans (OLM), and

Section Editor: Ramaswamy Kalyanasundaram

Ewa Długosz

ewa_dlugosz@sggw.pl

1 Division of Parasitology, Department of Preclinical Sciences, Faculty of Veterinary Medicine, Warsaw University of Life Sciences-SGGW, Ciszewskiego 8, 02-786 Warsaw, Poland

2 W. Stefański Institute of Parasitology, Twarda 51/55, 00-818 Warsaw, Poland cerebral or neurotoxocariasis (NT), which is considered as the most cryptic of all disease syndromes (Holland 2017). However, the most common syndrome and the most difficult to diagnose is covert toxocariasis (CT) with many unspecific symptoms such as arthralgia, lymphadenopathy, fever, or headaches. Toxocara worms also contribute to the development of allergic diseases, including asthma, chronic urticaria, or angioedema (Magnaval et al. 2001; Pinelli et al. 2008).

Many studies concerning the interaction between Toxocara and the immune system come from experiments conducted in murine model of the disease (Kuroda et al. 2001; Pinelli et al. 2008; Faz-López et al. 2013; Długosz et al. 2015). These reports show that a Th2 response is predominant. T cells produce IL-4 and IL-5 cytokines after contact with $T$. canis excretory-secretory antigens (TES). At the same time, IFN- $\gamma$ and TNF- $\alpha$ are downmodulated and regulatory cytokines IL10 and TGF- $\beta$ are upregulated (Kuroda et al. 2001; Fan et al. 2004). Th1 and Th17 immune responses are strongly inhibited in mice infected with $T$. canis comparing with control animals (Długosz et al. 2015). This strong Th2 response allows for the establishment of heavy parasite loads in different tissues, but at the same time, it protects mice from the development of severe pathology in lungs (Faz-López et al. 2013). 
Previous reports show that healthy human $\mathrm{T}$ cells produce significant amounts of IL-4 and IL-5, but no IL- 2 or IFN- $\gamma$ after stimulation with TES (Del Prete et al. 1991). Inuo et al. (1995) reported that human PBMC proliferate in response to Toxocara adult worm antigen (TcAg) and that their differentiation into $\mathrm{Th} 2$ cells is not obvious as IL- 2 and IFN- $\gamma$ mRNA expression was noted along with the expression of IL- 4 and IL-5 mRNA. Moreover TcAg was also shown to stimulate the proliferation of human B cells (Wang et al. 1995). In a more recent clinical study, the level of cytokines in sera of patients with VLM was analysed. The study shows that in children with hepatic involvement, IL-4, IL-6, and IL-10 levels are elevated together with eosinophilia and IgE hyperimmunoglobulinemia (MazurMelewska et al. 2014). The authors suppose that the pathology of VLM results from the imbalance between pro-inflammatory and anti-inflammatory cytokines in these patients.

Human toxocariasis is considered as a neglected parasitic infection. More efforts should be made to enrich our understanding of the infection process in the human host. Using the feasible in vitro models and comparing the results with those obtained in the mouse model will bring us forward to fill many gaps in our knowledge of toxocariasis. Therefore, the aim of the study was the analysis of human macrophage in vitro cytokine response to $T$. canis antigens and the evaluation of the possible signalling pathways involved in this response.

\section{Materials and methods}

\section{Antigen preparation}

Collection of TES from in vitro larvae culture and the production of recombinant T. canis mucins in Pichia pastoris yeast is described elsewhere (Długosz et al. 2015). In order to eliminate sugar moieties, TES and recombinant mucins were treated with sodium metaperiodate according to the method described by Tawill et al. (Tawill et al. 2004) and the deglycosylation process was monitored by protein electrophoresis (Długosz and Wisniewski 2016).

\section{Cell culture}

The THP-1 human monocyte cell line was purchased from the American Type Culture Collection. Cells were maintained in culture medium (RPMI 1640 supplemented with $10 \%$ foetal bovine serum, $2-\mathrm{mM}$ glutamine, $100-\mathrm{U} / \mathrm{ml}$ penicillin, $100-\mu \mathrm{g} / \mathrm{ml}$ streptomycin) at $37^{\circ} \mathrm{C}$ in a humidified atmosphere of $5 \% \mathrm{CO}_{2}$. The cells were seeded into 24 -well plates at a concentration of $1 \times 10^{6} / \mathrm{ml}$ in a volume of $1 \mathrm{ml} /$ well. The cells were differentiated into macrophages by the addition of 100-ng/ml phorbol 12-myristate 13-acetate (PMA) for $72 \mathrm{~h}$. After differentiation, the cells were washed twice with fresh media w/o PMA and stimulated with ES $(5 \mu \mathrm{g} / \mathrm{ml})$, a mixture of recombinant mucins $(1.25 \mu \mathrm{g} / \mathrm{ml}$ of each Tc-MUC- 2 , TcMUC-3, Tc-MUC-4 and Tc-MUC-5) or individual mucins $(1.25 \mu \mathrm{g} / \mathrm{ml})$ with or without lipopolysaccharide (LPS) $(100 \mathrm{ng} / \mathrm{ml})$. The same stimulation procedures were performed with deglycosylated antigens. The stimulation culture media were collected after $24 \mathrm{~h}$ and stored at $-70^{\circ} \mathrm{C}$ until use.

\section{Cytokine assays}

The concentrations of TNF- $\alpha$, IL-1 $\beta$, IL-6, IL-12p70, and IL10 were determined using the commercial ELISA kits OptEIA Tм Set Human (BD Biosciences) and IL-23 using DuoSet ELISA (R\&D Systems) according to manufacturer instruction. Experiments were performed independently in triplicate. Statistical analysis was performed by Student's $t$ test. A value of $p<0.05$ was considered to be significant. Analysis was done using Statgraphics Plus 4.1 software. Results are shown as mean $\pm \mathrm{SD}$.

\section{Phospho-kinase array}

The phospho-antibody array analysis was performed using the Proteome Profiler Human Phospho-Kinase Array Kit from R\&D Systems according to the manufacturer's instructions. Proteins were isolated from THP-1 macrophages stimulated for $24 \mathrm{~h}$ with a mixture of recombinant glycosylated and deglycosylated mucins $(1.25 \mu \mathrm{g} / \mathrm{ml}$ of each Tc-MUC-2, TcMUC-3, Tc-MUC-4, and Tc-MUC-5) and from unstimulated control cells. The protein concentration was measured using a Pierce TM BCA Protein Assay Kit (Thermo Scientific). Preblocked nitrocellulose membranes of the Human PhosphoKinase Arrays were incubated with equal amounts of cellular extract overnight at $4{ }^{\circ} \mathrm{C}$ on a rocking platform. The membranes were washed three times with $1 \times$ Wash Buffer (R\&D Systems) to remove the unbound proteins and were then incubated with a mixture of biotinylated detection antibodies and streptavidin-HRP antibodies. Chemiluminescent detection reagents were applied to detect spot densities. Membranes were exposed to X-ray film for 3, 5, and $10 \mathrm{~min}$. Array images were analysed using image analysis software Quantity One (Biorad).

\section{Results and discussion}

The interaction between Toxocara parasites and the immune system of the human host is not fully understood. Therefore we decided to analyse the effect of roundworm antigens on cytokine release by human macrophages since these cells are reliable model for other organisms (Alvarado et al. 2017; Baska et al. 2017). Macrophages are a heterogeneous group of immune cells and their phenotype and functions are regulated by the surrounding micro-environment (reviewed in 
Shapouri-Moghaddam et al. 2018). We used the THP-1 human leukaemia monocytic cell line as it has been used with success in studies concerning monocyte/macrophage functions, mechanisms, and signalling pathways during other helminth infections (Johnston et al. 2010; Baska et al. 2013; Silva-Álvarez et al. 2016; Zawistowska-Deniziak et al. 2017).

Stimulation of THP-1 cells with $T$. canis molecules, especially mucins resulted in the production of TNF- $\alpha$, IL-1 $\beta$, IL-6, IL-10, and very low amounts of IL-12p70 (Fig. 1). IL-23 was detected only after additional LPS stimulation (data not shown), and no significant differences between groups were noted.

Many helminth parasites induce IL-10 production and different sources of this immunoregulatory cytokine have been described. For example, IL-10 producing regulatory T cells are induced by Schistosoma-modulated dendritic cells (Van der Kleij et al. 2002) whilst filarial ES-62 antigen induces IL-10 production by peritoneal B1 lymphocytes (Wilson et al. 2003). Macrophages showing a regulatory phenotype after induction by helminth cystatins are another source of IL-10 (Klotz et al. 2011). T. canis ES antigens stimulate the production of IL-10 by splenocytes and macrophages of infected, but not control mice (Kuroda et al. 2001; Długosz et al. 2015). In this study, the amount of IL-10 secreted by THP-1 cells after stimulation with TES did not differ from the control; however, it was significantly higher after stimulation with recombinant mucins (Fig. 1). All investigated molecules increased IL-10 production by macrophages when costimulated with LPS.

We noted a significant increase in IL-6 production after stimulation with all tested antigens, and surprisingly the amount secreted by cells treated with mucins was about 25fold higher (Fig. 1). Serum IL-6 level in children with VLM was also significantly higher comparing with healthy controls (Mazur-Melewska et al. 2014). IL-6 production by T. canisinfected mouse splenocytes was also highly upregulated after TES and mucin stimulation; however, in this case, mucins were less effective (Długosz et al. 2015). On contrary, Kuroda et al. (2001) did not detect the production of IL- 6 by murine macrophages.

The role of IL- 6 in T. canis infections remains to be determined. It is not likely that it would favour parasite survival by restricting the Th2 response as it was described in the case of Heligmosomoides polygyrus in mice (Smith and Maizels 2014). During Toxocara infection, the limitation of Th2 response is not beneficial to either the parasite, as worm number is reduced, nor for the host as the pathology is augmented (Faz-López et al. 2013). IL-6 is a cytokine with a wide range of functions, one of which is the regulation of acute and chronic inflammation (Naka et al. 2002). Together with TGF- $\beta$, it also plays a pivotal role in favouring Th17 differentiation (Basso et al. 2009). Studies from the mouse model of toxocariasis concerning the involvement of Th17 response are not convergent. IL-17 was noted in mouse sera at 14-day post-infection (Resende et al. 2015), on contrary, it was not produced by splenocytes at 21-day post-infection (Długosz et al. 2015). There are no reports on IL-17 production during the course of infection in humans; therefore, the development of Th17 cells and the possible role of IL- 6 during human toxocariasis remains to be investigated.

TNF- $\alpha$ was also upregulated in THP- 1 cells, after treatment with $T$. canis molecules (Fig. 1). Previously secretion of TNF- $\alpha$ by mouse immune cells was shown to be downmodulated (Kuroda et al. 2001; Długosz et al. 2015). Here we show that even though mucins alone increase TNF- $\alpha$ production, they have the opposite effect after simultaneous cell stimulation with LPS.

A similar pattern of cytokine production was observed for IL-1 $\beta$ (Fig. 1), with the exception that cell stimulation with mucins further upregulated its secretion after LPS treatment. Production of IL-1 $\beta$ by epithelial cells was noted during Trichinella spiralis (Li et al. 1998) and H. polygyrus infections (Zaiss et al. 2013). Increased production of IL-1 $\beta$ suppresses the release of innate cytokines, resulting in suboptimal type 2 immunity and allowing pathogen chronicity (Zaiss et al. 2013).

Macrophages polarise into two major populations with different functions. Classically activated or inflammatory macrophages (M1) are typically induced by Th1 cytokines, such as IFN- $\gamma$ and TNF- $\alpha$ or by bacterial LPS. Alternatively activated or anti-inflammatory (M2) macrophages are polarised by Th2 cytokines IL-4 and IL-13. M2 macrophages were further divided into four different subsets (M2a, M2b, M2c, and M2d) depending on the activating stimulus (Martinez et al. 2008). During our study THP-1 macrophages secreted both proinflammatory (IL-1 $\beta$, IL-6, and TNF- $\alpha$ ) and regulatory (IL10) cytokines. Such cytokine profile is typical for so-called M2b macrophages. These cells are induced by immune complexes and TLR ligands and take part in Th2 activation and immunoregulation (Shapouri-Moghaddam et al. 2018).

M2 macrophages are induced by many parasite antigens (Hewitson et al. 2009; Peon et al. 2013), and their presence was also confirmed in Toxocara infected tissues (Faz-López et al. 2013). M2b macrophages were so far described only in case of Leishmania major (Filardy et al. 2018) and Acanthocheilonema viteae (Klotz et al. 2011) infections.

Our studies show that T. canis mucins stimulate THP-1 cells to produce significantly larger amounts of cytokines compared with unstimulated cells. Mucins are group of heavily Oglycosylated high molecular weight proteins constituting the TES-120 fraction (Gems and Maizels 1996; Loukas et al. 2000). The major role of TES-120 mucins is the formation of larval surface coat (Page et al. 1992) and protection from antibody and eosinophil attack (Smith et al. 1981; Badley et al. 1987). O-methylated Toxocara glycans are specific targets for host antibodies which prove that they are strongly recognised by the host immune system (Fong and Lau 2004; Schabussova et al. 2007; Długosz and Wisniewski 2016). Previously we have shown that mucins stimulate the in vitro production of IL-4, IL-5, 
Fig. 1 Cytokine production by THP-1 macrophages stimulated with: TES; deglycosylated TES (dTES); recombinant mucins (MUC); deglycosylated mucins (dMUC), and unstimulated control cells with and without simultaneous LPS treatment. Results are presented as mean of calculated concentration $[\mathrm{pg} / \mathrm{ml}] \pm \mathrm{SD}$. Statistical analysis was performed by Student's $t$ test. A value of $P<0.05$ was considered to be significant. Significant differences between groups are marked with: $* p<0.05, * * p<0.01$, *** $p$ $<0.001, * * * * p<0.0001, \mathbf{a}-\mathbf{e}$ a

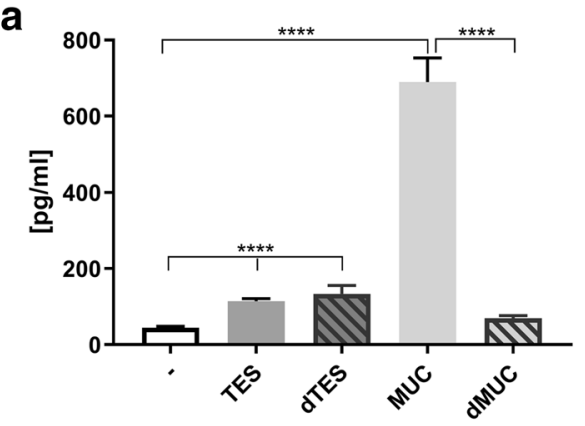

b

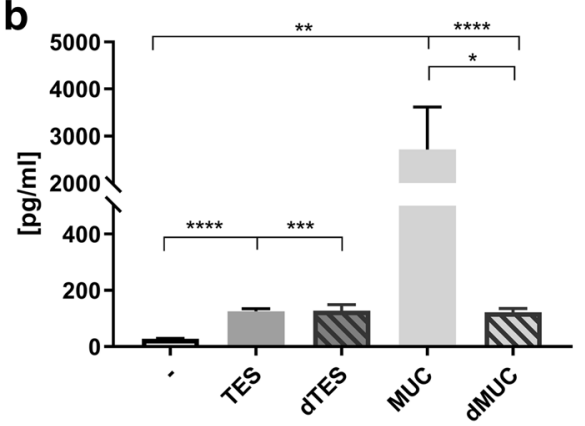

C

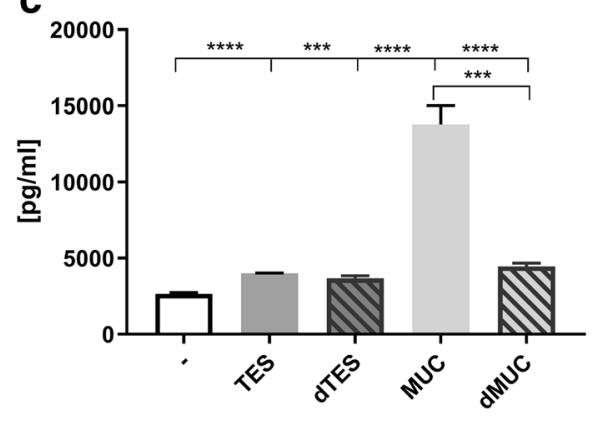

d

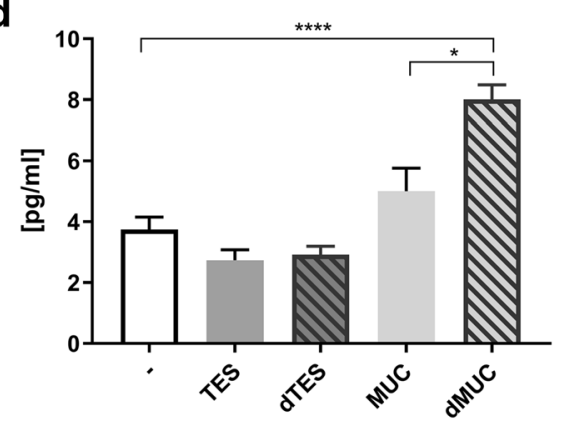

e

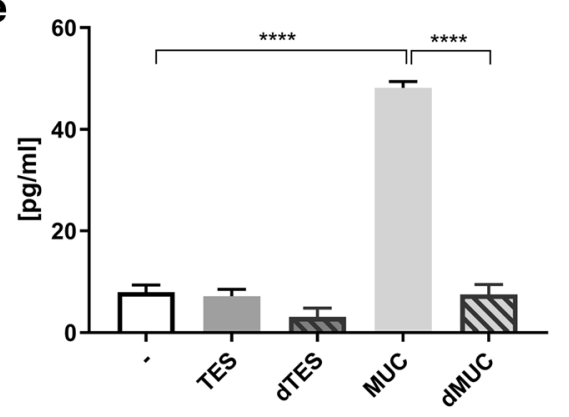

TNF $\alpha$

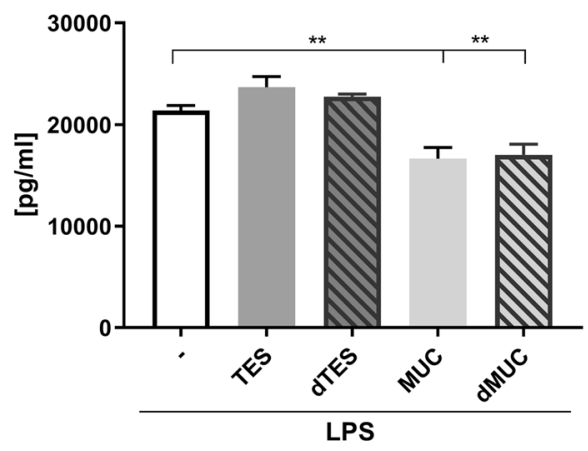

IL6

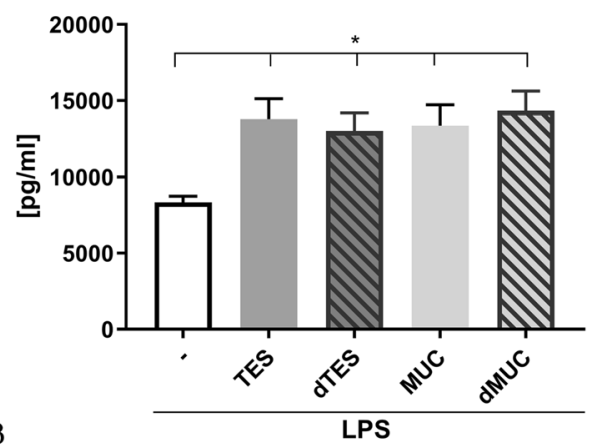

IL1 $\beta$

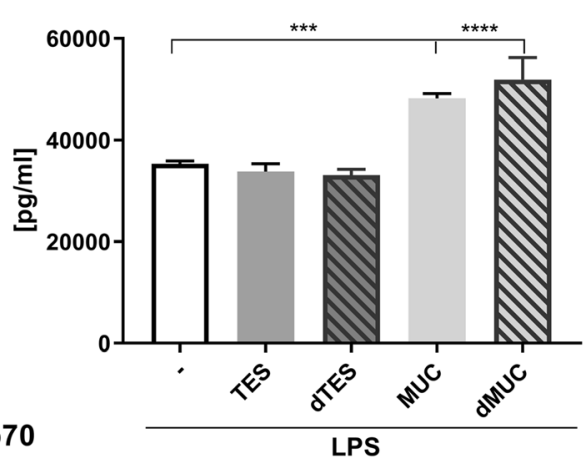

IL12p70
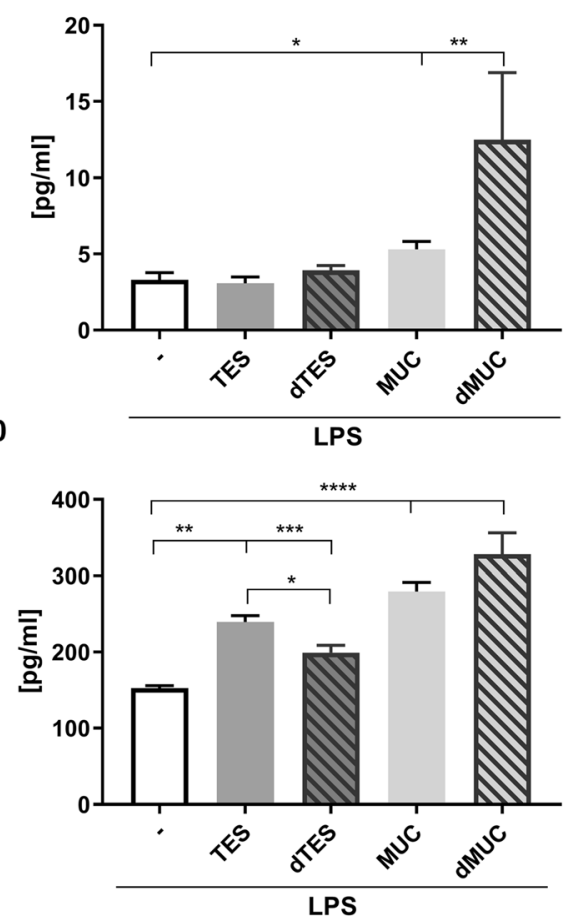
IL-6, and TGF- $\beta$ cytokines by splenocytes from $T$. canis infected mice; however, their effect was less intensive compared with TES antigens (Długosz et al. 2015).

We have also analysed cytokine secretion after cell stimulation with single recombinant mucins (Table 1). In most cases, particular mucins elicited a very similar effect. We only noted two significant differences, one of which was increased TNF- $\alpha$ production after MUC-4 treatment compared with MUC-2 and MUC-3 (Table 1). Apart from other T. canis mucins, MUC-4 is either not secreted or is expressed at a relatively low level (Loukas et al. 2000). Moreover MUC-4 shows a serine protease activity and degrades albumin and IgG immunoglobulins (González-Páez et al. 2014). These features may explain the different effect of MUC- 4 on TNF- $\alpha$ production by THP-1 cells.

Another difference was noted in the case of MUC-5, precisely its deglycosylated form which induced significantly higher production of IL-12p70 compared with other mucins (Table 1). MUC-5 protein is probably responsible for the total effect of the mixture of deglycosylated mucins which also upregulated IL-12p70 secretion (Fig. 1). MUC-5 is both larger and more divergent than other mucins, and it is unlikely that it is a member of TES-120 family of surface coat proteins (Doedens et al. 2001). Moreover, MUC-5 ShK/SXC domains are only distantly related to those present in all other $T$. canis mucins. Perhaps the deglycosylation uncovered these unique domains enabling interaction with receptors other than carbohydrate-binding C-type lectin receptors (CLRs) allowing different type of macrophage activation.

Our results clearly show that stimulation of THP-1 cells with mucins induced a glycan-dependent cytokine response. Macrophage treatment with deglycosylated mucins was at least three times less effective comparing to intact glycoprotein molecules (Fig. 1, Table 1). Other studies have already proved that

Table 1 Cytokine production by THP-1 macrophages stimulated with $T$. canis recombinant glycosylated and deglycosylated mucins

\begin{tabular}{|c|c|c|c|c|c|c|c|c|c|c|c|c|c|}
\hline \multirow{3}{*}{$\begin{array}{l}\text { TNF- } \alpha \\
\end{array}$} & \multirow[b]{3}{*}{ MUC-2 } & \multicolumn{3}{|c|}{ Glycosylated } & \multicolumn{3}{|c|}{ Deglycosylated } & \multicolumn{6}{|l|}{ LPS } \\
\hline & & & & & & & & \multicolumn{3}{|c|}{ Glycosylated } & \multicolumn{3}{|c|}{ Deglycosylated } \\
\hline & & 286 & \pm & $43^{\mathrm{ab}}$ & 84 & \pm & $9^{\mathrm{a}}$ & 21106 & \pm & $855^{\text {bef }}$ & 26106 & \pm & $1623^{\text {ah }}$ \\
\hline & MUC-3 & 304 & \pm & $41^{\mathrm{ab}}$ & 79 & \pm & $6^{\mathrm{a}}$ & 21609 & \pm & $2208^{\mathrm{ef}}$ & 22700 & \pm & 943 \\
\hline & MUC-4 & 818 & \pm & $240^{\mathrm{ab}}$ & 86 & \pm & $22^{\mathrm{a}}$ & 27179 & \pm & $2438^{\mathrm{a}}$ & 27755 & \pm & $2012^{\text {ah }}$ \\
\hline & MUC-5 & 522 & \pm & $245^{\mathrm{ab}}$ & 69 & \pm & $8^{\mathrm{a}}$ & 26752 & \pm & $1739^{\mathrm{a}}$ & 25602 & \pm & $2107^{\mathrm{a}}$ \\
\hline & Control & 44 & \pm & 10 & & & & 21420 & \pm & 1183 & & & \\
\hline \multirow[t]{5}{*}{ IL-1 $\beta$} & MUC-2 & 6568 & \pm & $686^{\mathrm{ab}}$ & 3783 & \pm & $491^{\mathrm{a}}$ & 34556 & \pm & 853 & 35736 & \pm & 2438 \\
\hline & MUC-3 & 6629 & \pm & $747^{\mathrm{ab}}$ & 3688 & \pm & $186^{\mathrm{a}}$ & 35093 & \pm & 4850 & 37014 & \pm & 2811 \\
\hline & MUC-4 & 6755 & \pm & $624^{\mathrm{ab}}$ & 4360 & \pm & $686^{\mathrm{a}}$ & 39517 & \pm & 4632 & 38506 & \pm & 4013 \\
\hline & MUC-5 & 6548 & \pm & $892^{\mathrm{ab}}$ & 4260 & \pm & $465^{\mathrm{a}}$ & 35197 & \pm & $2526^{\mathrm{b}}$ & 42776 & \pm & $1857^{\text {ah }}$ \\
\hline & Control & 2653 & \pm & 212 & & & & 35389 & \pm & 1324 & & & \\
\hline \multirow[t]{5}{*}{ IL-6 } & MUC-2 & 155 & \pm & $3^{\mathrm{ab}}$ & 49 & \pm & 37 & 10740 & \pm & $986^{\mathrm{a}}$ & 10526 & \pm & 2023 \\
\hline & MUC-3 & 189 & \pm & $61^{\mathrm{a}}$ & 84 & \pm & $29^{\mathrm{a}}$ & 10350 & \pm & 3472 & 10334 & \pm & $1352^{\mathrm{a}}$ \\
\hline & MUC-4 & 211 & \pm & $19^{\mathrm{ab}}$ & 40 & \pm & 33 & 11555 & \pm & $2723^{\mathrm{a}}$ & 10107 & \pm & 2940 \\
\hline & MUC-5 & 121 & \pm & $49^{\mathrm{a}}$ & 54 & \pm & $15^{\mathrm{a}}$ & 10995 & \pm & 2947 & 9570 & \pm & 3360 \\
\hline & Control & 27 & \pm & 4 & & & & 8349 & \pm & 866 & & & \\
\hline \multirow[t]{5}{*}{ IL-10 } & MUC-2 & 15 & \pm & $3^{\mathrm{a}}$ & 4 & \pm & 3 & 198 & \pm & $18^{\mathrm{a}}$ & 209 & \pm & $8^{\mathrm{a}}$ \\
\hline & MUC-3 & 16 & \pm & $3^{\mathrm{a}}$ & 3 & \pm & 3 & 190 & \pm & $17^{\mathrm{a}}$ & 202 & \pm & $19^{\mathrm{a}}$ \\
\hline & MUC-4 & 23 & \pm & $6^{\mathrm{a}}$ & 4 & \pm & 5 & 231 & \pm & $11^{\mathrm{ab}}$ & 186 & \pm & $8^{\mathrm{a}}$ \\
\hline & MUC-5 & 22 & \pm & $8^{\mathrm{a}}$ & 8 & \pm & 2 & 232 & \pm & $25^{\mathrm{ab}}$ & 185 & \pm & $11^{\mathrm{a}}$ \\
\hline & Control & 8 & \pm & 3 & & & & 152 & \pm & 8 & & & \\
\hline \multirow[t]{5}{*}{ IL-12p70 } & MUC-2 & 3 & \pm & 2 & 6 & \pm & 5 & 6 & \pm & $2^{\mathrm{a}}$ & 8 & \pm & $4^{a}$ \\
\hline & MUC-3 & 5 & \pm & 4 & 5 & \pm & $3^{\mathrm{i}}$ & 5 & \pm & $1^{\mathrm{a}}$ & 6 & \pm & $0^{\mathrm{ai}}$ \\
\hline & MUC-4 & 4 & \pm & 2 & 6 & \pm & $3^{\mathrm{i}}$ & 5 & \pm & $1^{\mathrm{a}}$ & 6 & \pm & $1^{\mathrm{ai}}$ \\
\hline & MUC-5 & 4 & \pm & 1 & 10 & \pm & $0^{\mathrm{a}}$ & 4 & \pm & 1 & 17 & \pm & $6^{\mathrm{a}}$ \\
\hline & Control & 4 & \pm & 1 & & & & 3 & \pm & 2 & & & \\
\hline
\end{tabular}

Results are presented as mean of calculated concentration $[\mathrm{pg} / \mathrm{ml}] \pm \mathrm{SD}$. Statistical analysis was performed by Student's $t$ test. A value of $P<0.05$ was considered to be significant. Significant differences between groups are marked with: ${ }^{\mathrm{a}}$ vs unstimulated cells; ${ }^{\mathrm{b}}$ glycosylated vs deglycosylated mucinstimulated cells; ${ }^{\mathrm{c}}$ vs MUC-2-stimulated cells; ${ }^{\mathrm{d}}$ vs MUC-3-stimulated cells; ${ }^{\mathrm{e}} \mathrm{vs}$ MUC-4-stimulated cells; ${ }^{\mathrm{f}} \mathrm{vs}$ MUC-5-stimulated cells; ${ }^{\mathrm{g}}$ vs dMUC-2stimulated cells; ${ }^{\text {h }}$ vs dMUC-3-stimulated cells; ${ }^{\text {i }}$ vs dMUC-5-stimulated cells 
schistosome and filarial glycans are responsible for the induction of Th2 cytokine production (Okano et al. 1999; Tawill et al. 2004). These carbohydrates interact with pattern-recognition receptors (PRRs) on dendritic cells and macrophages, especially Ctype lectin receptors (CLRs) which together with toll-like receptors (TLRs) are instrumental in regulation of adaptive immunity (Prasanphanich et al. 2013). Parasitic glycans are bound by several CLRs such as DC-SIGN, mannose receptor (MR), or galactose-type lectin (MGL) (Everts et al. 2012; Meevissen et al. 2012; Klaver et al. 2013). TES antigens were also found to bind human DC-SIGN receptor (Schabussova et al. 2007).

The MGL receptor binds human mucin 1 which becomes overexpressed and aberrantly glycosylated upon malignant transformation. These aberrant glycans on tumour cells may have the ability to suppress antitumor immune responses through activation of the MGL receptor on dendritic cells (Zizzari et al. 2015). It is therefore possible that Toxocara mucins also bind MGL and modulate host immune response through such interaction. However, in depth investigations need to be conducted to confirm which CLR receptors might be engaged in immune regulation by $T$. canis molecules.

To better understand the influence of glycosylated mucins on cytokine production by THP-1 macrophages, we decided to analyse the phosphorylation profile of kinases involved in signal transduction. The use of the commercial Proteome ProfilerHuman Phospho-Kinase Array enabled a simultaneous analysis of 43 kinase phosphorylation sites. The most intensive, about 4-fold, increase in phosphorylation was observed in the case of heat shock protein 27 (HSP27) in MUC and dMUCtreated cells compared with control (Fig. 2). On contrary,
HSP60 was phosphorylated at an equal level in all examined cases. HSPs such as HSP60, HSP70, and HSP90 have been reported to play important roles in antigen presentation, activation of lymphocytes and macrophages, and activation and maturation of dendritic cells (reviewed by Tsan and Gao 2009). HSP27 belongs to small HSPs, and it is intensively upregulated during differentiation from monocytes to macrophages and promotes their survival during inflammation by inhibiting caspase 3 activation, binding to $\mathrm{Bcl}-2$ family members and sequestration of cytochrome c (Voss et al. 2007; Gonzalez-Mejia and Doseff 2009). Moreover, HSP27 induces IL-10 production in human monocytes via activation of p38 signalling independently of TNF- $\alpha$ activation (De et al. 2000). Extracellular HSP27 has been shown to act as a signalling molecule and activate NFk $\beta$ in macrophages leading to pro-inflammatory IL-1 $\beta$ and TNF- $\alpha$ as well as anti-inflammatory factors IL-10 and GM-CSF (Salari et al. 2013).

The phosphorylation of MAPK family members such as p38 and JNK as well as c-Jun transcription factor noted in macrophages stimulated by analysed antigens suggest that TLR signalling might be involved (Kawasaki and Kawai 2014). Interestingly, the phosphorylation of these factors was the most intensive in cells stimulated with deglycosylated mucins which suggests that these cells should produce higher amounts of proinflammatory cytokines compared with cells treated with intact mucins. However, this was only true for IL-12p70 which was upregulated by deglycosylated mucins (Fig. 1).

This fact might be explained by higher phosphorylation of the CREB transcription factor in these cells. Phosphorylated CREB has been proposed to directly inhibit NF- $\mathrm{k} \beta$ activation
Fig. 2 Heatmap of intracellular kinase phosphorylation fold changes measured by the Proteome Profiler Human Phospho-Kinase Array in THP-1 macrophages stimulated with intact and deglycosylated mucins as well as in control unstimulated cells. Results are shown as the adjusted mean volume $(\mathrm{OD} \times$ $\mathrm{mm} 2) \pm \mathrm{SD}$ of two repeats on membrane. The average intensity of the pixels in background volume was calculated and subtracted from each pixel in all standard and unknown

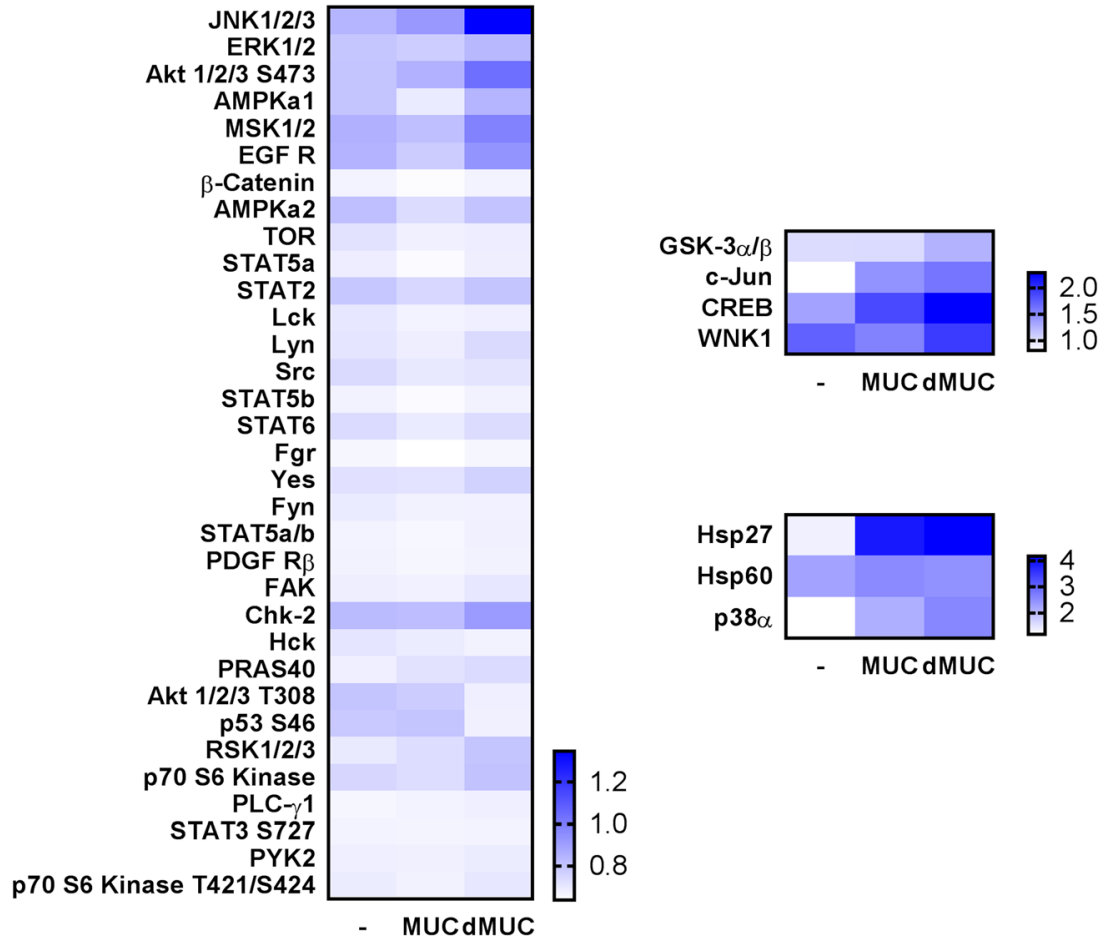


by blocking the binding of CREB binding protein to the NF$\mathrm{k} \beta$ complex, thereby limiting pro-inflammatory responses, including the production of IL-2, IL-6, IL-10, and TNF- $\alpha$ (Wen et al. 2010). CREB may be phosphorylated by several kinases i.a. cAMP-dependent protein kinase (AMPK) or pp90 ribosomal S6 kinase (pp90 RSK also known as RSK2) (Wen et al. 2010) both of which were also phosphorylated more intensively in dMUC treated THP-1 cells (Fig. 2). Many reports show that AMPK stimulates SIRT1, PGC- $1 \alpha$, p53, and FoxO factors which can inhibit the NF- $k \beta$ signalling with different mechanisms and therefore suppress the process of inflammation and expand the lifespan in diverse types of cells and tissues (reviewed by Salminen et al. 2011).

Our results also show that stimulation of macrophages results in higher phosphorylation of GSK- $3 \alpha / \beta$ is and less phosphorylation of p53 (Fig. 2). Phosphorylation of GSK-3 $\alpha / \beta$ results in its inactivation which leads to anti-apoptotic effects and cell survival (Maurer et al. 2014). Phosphorylation of the tumour suppressor p53 at S46 site is more intensive in cells directed toward apoptosis (Smeenk et al. 2011) what again proves that signalling in dMUC-treated cells led to cell survival.

However AMPK activation was not observed in macrophages treated with mucins. In turn, another kinase AKT, also known as protein kinase B (PKB), was activated (Fig. 2). Several points of cross-regulation exist between the PI3KAKT and AMPK pathways, leading to both reciprocal pathway regulation and convergent regulation of downstream processes (Manning and Toker 2017). Several studies show that AKT kinase pathway is targeted by protozoan parasites leading to the inhibition of apoptosis in infected cells (Chuenkova and PereiraPerrin 2010; Quan et al. 2013; Gupta et al. 2016).

Phosphorylation of two residues (S473 and T308) is required for maximal activation of the AKT kinase (Alessi et al. 1996). These two sites were phosphorylated in MUCtreated cells, whilst in dMUC-stimulated cells only S473 site was phosphorylated (Fig. 2). AKT-mediated phosphorylation of FoxO leads to its binding and cytosolic sequestration by 143-3 proteins, thereby attenuating the expression of its gene targets responsible for cell survival, proliferation, and growth (Brunet et al. 2001; Manning and Toker 2017).

PI3K/AKT pathway and its downstream targets have recently emerged as central regulators of activation phenotype in macrophages. It regulates macrophage survival, migration, and proliferation but also orchestrates the response to different metabolic and inflammatory signals in macrophages (Covarrubias et al. 2015). The PI3K/AKT pathway is activated by TLR4 and other pathogen recognition receptors, cytokine and chemokine, and Fc receptors, modulating downstream signals that control cytokine production (reviewed by Vergadi et al. 2017). AKT is crucial for M2 activation as its inhibition abrogates the upregulation of M2 genes (Byles et al. 2013). Several signals such as TGF- $\beta$ (Gong et al. 2012), IL10 (Park et al. 2011), and bone morphogenetic protein-7
(BMP-7) (Rocher and Singla 2013) promote M2 polarization via PI3K/AKT signalling.

In conclusion, we have shown that TES molecules, especially mucins induce cytokine production by human THP-1 macrophages. The secretion of cytokines after mucin stimulation was glycan dependent. Sugar moieties also affected the phosphorylation of cellular kinases. Differences were noted especially in the activation of AMPK and AKT kinases in treated cells. The activation of AKT kinase seems crucial for intensive cytokine production.

The difference between cytokine levels secreted after TES and mucin stimulation was very significant. It must be pointed out that although mucins constitute a quite abundant component of TES products, they contain plenty of different molecules which obviously counterbalanced the effect induced by mucins. More efforts should be made to reveal the mechanisms of interaction of particular TES molecules with human immune cells. This will ensure a better understanding of the complex infection process during human toxocariasis.

Funding information This study was supported by a research grants no $\mathrm{N}$ N308 573540 and 2017/01/X/NZ6/00260 from the Polish National Science Center.

\section{Compliance with ethical standards}

Conflict of interest The authors declare that they have no conflict of interest.

Open Access This article is distributed under the terms of the Creative Commons Attribution 4.0 International License (http:// creativecommons.org/licenses/by/4.0/), which permits unrestricted use, distribution, and reproduction in any medium, provided you give appropriate credit to the original author(s) and the source, provide a link to the Creative Commons license, and indicate if changes were made.

\section{References}

Alessi DR, Andjelkovic M, Caudwell B, Cron P, Morrice N, Cohen P, Hemmings BA (1996) Mechanism of activation of protein kinase B by insulin and IGF-1. EMBO J 15:6541-6551

Alvarado R, To J, Lund ME, Pinar A, Mansell A, Robinson MW, O'Brien BA, Dalton JP, Donnelly S (2017) The immune modulatory peptide FhHDM-1 secreted by the helminth Fasciola hepatica prevents NLRP3 inflammasome activation by inhibiting endolysosomal acidification in macrophages. FASEB J 31:85-95. https://doi.org/10. 1096/fj.201500093R

Badley JE, Grieve RB, Bowman DD, Glickman LT (1987) Immunemediated adherence of eosinophils to Toxocara canis infective larvae: the role of excretory-secretory antigens. Parasite Immunol 9:133-143

Bąska P, Wiśniewski M, Krzyżowska M, Długosz E, Zygner W, Górski P, Wędrychowicz H (2013) Molecular cloning and characterisation of in vitro immune response against astacin-like metalloprotease AceMTP-2 from Ancylostoma ceylanicum. Exp Parasitol 133:472-482. https://doi.org/10.1016/j.exppara.2013.01.006

Baska P, Norbury LJ, Zawistowska-Deniziak A, Wiśniewski M, Januszkiewicz K (2017) Excretory/secretory products from two 
Fasciola hepatica isolates induce different transcriptional changes and IL-10 release in LPS-activated bovine "BOMA" macrophages. Parasitol Res 116:2775-2782. https://doi.org/10.1007/s00436-017-5588-6

Basso AS, Cheroutre H, Mucida D (2009) More stories on Th17 cells. Cell Res 19:399-411. https://doi.org/10.1038/cr.2009.26

Brunet A, Park J, Tran H, Hu LS, Hemmings BA, Greenberg ME (2001) Protein kinase SGK mediates survival signals by phosphorylating the Forkhead transcription factor FKHRL1 (FOXO3a). Mol Cell Biol 21:952-965. https://doi.org/10.1128/MCB.21.3.952-965.2001

Byles V, Covarrubias AJ, Ben-sahra I, Lamming DW (2013) The TSCmTOR pathway regulates macrophage polarization. Nat Commun 4 : 2834. https://doi.org/10.1038/ncomms3834

Chuenkova M, PereiraPerrin M (2010) Trypanosoma cruzi targets Akt in host cells as an intracellular antiapoptotic strategy. Sci Signal 2:120. https://doi.org/10.1126/scisignal.2000374

Covarrubias AJ, Aksoylar HI, Horng T (2015) Control of macrophage metabolism and activation by mTOR and Akt signaling. Semin Immunol 27:286-296. https://doi.org/10.1016/j.smim.2015.08.001.Control

De AK, Kodys KM, Yeh BS, Miller-Graziano C (2000) Exaggerated human monocyte IL-10 concomitant to minimal TNF- $\alpha$ induction by heat-shock protein 27 (Hsp27) suggests Hsp27 is primarily an antiinflammatory stimulus. J Immunol 165:3951-3958. https://doi. org/10.4049/jimmunol.165.7.3951

Del Prete GF, De Carli M, Mastromauro C, Biagiotti R, Macchia D, Falagiani P, Ricci M, Romagnani S (1991) Purified protein derivative of Mycobacterium tuberculosis and excretory-secretory antigen(s) of Toxocara canis expand in vitro human T cells with stable and opposite (type $1 \mathrm{~T}$ helper or type $2 \mathrm{~T}$ helper) profile of cytokine production. J Clin Invest 88:346-350. https://doi.org/10.1172/JCI115300

Długosz E, Wisniewski M (2016) Toxocara canis glycans influence antigen recognition by mouse IgG1 and IgM antibodies. Acta Parasitol 61:191-194. https://doi.org/10.1515/ap-2016-0026

Długosz E, Wasyl K, Klockiewicz M, Wiśniewski M (2015) Toxocara canis mucins among other excretory-secretory antigens induce in vitro secretion of cytokines by mouse splenocytes. Parasitol Res 114:3365-3371. https://doi.org/10.1007/s00436-015-4561-5

Doedens A, Loukas A, Maizels RM (2001) A cDNA encoding Tc-MUC5, a mucin from Toxocara canis larvae identified by expression screening. Acta Trop 79:211-217

Everts B, Hussaarts L, Driessen NN, Meevissen MHJ, Schramm G, van der Ham AJ, van der Hoeven B, Scholzen T, Burgdorf S, Mohrs M, Pearce EJ, Hokke CH, Haas H, Smits HH, Yazdanbakhsh M (2012) Schistosome-derived omega-1 drives Th2 polarization by suppressing protein synthesis following internalization by the mannose receptor. J Exp Med 209:1753-1767. https://doi.org/10.1084/jem.20111381

Fan CK, Hung CC, Lin YH, Li MH, Su KE (2004) Enhanced expression of transforming growth factor-beta1 in inflammatory cells and secretory granules in Paneth cells in the small intestine of mice infected with Toxocara canis. Parasitol Res 94:397-404. https://doi.org/ 10.1007/s00436-004-1233-2

Faz-López B, Ledesma-Soto Y, Romero-Sánchez Y, Calleja E, MartínezLabat P, Terrazas LI (2013) Signal transducer and activator of transcription factor 6 signaling contributes to control host lung pathology but favors susceptibility against Toxocara canis infection. Biomed Res Int 696343. https://doi.org/10.1155/2013/ 6963432013:13-17

Filardy AA, Pires DR, Nunes MP, Takiya CM, Freire-de-lima CG, Flavia L, Dosreis GA (2018) Proinflammatory clearance of apoptotic neutrophils induces an IL-12 low IL-10 high regulatory phenotype in macrophages. J Immunol 185:2044-2050. https://doi.org/10.4049/ jimmunol.1000017

Fong MY, Lau YL (2004) Recombinant expression of the larval excretory-secretory antigen TES-120 of Toxocara canis in the methylotrophic yeast Pichia pastoris. Parasitol Res 92:173-176. https://doi.org/10.1007/s00436-003-1020-5
Gems D, Maizels RM (1996) An abundantly expressed mucin-like protein from Toxocara canis infective larvae: the precursor of the larval surface coat glycoprotein. Proc Natl Acad Sci U S A 93:1665-1670

Gong D, Shi W, Yi SJ, Chen H, Groffen J, Heisterkamp N (2012) TGF $\beta$ signaling plays a critical role in promoting alternative macrophage activation. BMC Immunol 13:1. https://doi.org/10.1186/1471-2172-13-31

Gonzalez-Mejia ME, Doseff AI (2009) Regulation of monocytes and macrophages cell fate M. Front Biosci 14:2413-2431

González-Páez GE, Alba-Hurtado F, García-Tovar CG, Argüello-García R (2014) Proteinases in excretory-secretory products of Toxocara canis second-stage larvae: Zymography and modeling insights. Biomed Res Int 2014:418708-418709. https://doi.org/10.1155/2014/418708

Gupta P, Srivastav S, Saha S, Das PK, Ukil A (2016) Leishmania donovani inhibits macrophage apoptosis and pro-inflammatory response through AKT-mediated regulation of $\beta$-catenin and FOXO-1. Cell Death Differ 23:1815-1826. https://doi.org/10.1038/cdd.2016.101

Hewitson JP, Grainger JR, Maizels RM (2009) Helminth immunoregulation: the role of parasite secreted proteins in modulating host immunity. Mol Biochem Parasitol 167:1-11. https://doi.org/10.1016/j. molbiopara.2009.04.008

Holland CV (2017) Knowledge gaps in the epidemiology of Toxocara: the enigma remains. Parasitology 144:81-94. https://doi.org/10. 1017/S0031182015001407

Inuo G, Akao N, Kohsaka H, Saito I, Miyasaka N, Fujita K (1995) Toxocara canis adult worm antigen induces proliferative response of healthy human peripheral blood mononuclear cells. Parasite Immunol 17:77-84

Johnston MJG, Wang A, Catarino MED, Ball L, Phan VC, MacDonald JA, McKay DM (2010) Extracts of the rat tapeworm, Hymenolepis diminuta, suppress macrophage activation in vitro and alleviate chemically induced colitis in mice. Infect Immun 78:1364-1375. https://doi.org/10.1128/IAI.01349-08

Kawasaki T, Kawai T (2014) Toll-like receptor signaling pathways. Front Immunol 5:461. https://doi.org/10.3389/fimmu.2014.0046

Klaver EJ, Kuijk LM, Laan LC, Kringel H, van Vliet SJ, Bouma G, Cummings RD, Kraal G, Van Die I (2013) Trichuris suis-induced modulation of human dendritic cell function is glycan-mediated. Int J Parasitol 43:191-200. https://doi.org/10.1016/j.ijpara.2012.10.021

Klotz C, Ziegler T, Figueiredo AS, Rausch S, Hepworth MR, Obsivac N, Sers C, Lang R, Hammerstein P, Lucius R, Hartmann S (2011) A helminth immunomodulator exploits host signaling events to regulate cytokine production in macrophages. PLoS Pathog 7:e1001248. https://doi.org/10.1371/journal.ppat.1001248

Kuroda E, Yoshida Y, Shan BE, Yamashita U (2001) Suppression of macrophage interleukin-12 and tumour necrosis factor-alpha production in mice infected with Toxocara canis. Parasite Immunol 23:305-331. https://doi.org/10.1046/j.1365-3024.2001.00387.x

Li CKF, Seth R, Gray T, Bayston R, Mahida YR, Wakelin D (1998) Production of proinflammatory cytokines and inflammatory mediators in human intestinal epithelial cells after invasion by Trichinella spiralis. Infect Immun 66:2200-2206. https://doi.org/10.1149/1.3046648

Loukas A, Hintz M, Linder D, Mullin NP, Prkinson J, Tetteh KKA, Maizels RM (2000) A family of secreted mucins from the parasitic nematode Toxocara canis bears diverse mucin domains but shares similar flanking six-cysteine repeat motifs. J Biol Chem 275:39600 39607. https://doi.org/10.1074/jbc.M005632200

Ma G, Holland CV, Wang T, Hofmann A, Fan CK, Maizels RM, Hotez PJ, Gasser RB (2018) Human toxocariasis. Lancet Infect Dis 18: e14-e24. https://doi.org/10.1016/S1473-3099(17)30331-6

Magnaval JF, Glickman LT, Dorchies P, Morassin B (2001) Highlights of human toxocariasis. Korean J Parasitol 39:1-11. https://doi.org/10. 3347/kjp.2001.39.1.1

Manning BD, Toker A (2017) AKT/PKB signaling: navigating the network. Cell 169:381-405. https://doi.org/10.1016/j.cell.2017.04.001

Martinez FO, Sica A, Mantovani A, Locati M (2008) Macrophage activation and polarization. Bioscience 13:453-461. https://doi.org/10.2741/2692 
Maurer U, Preiss F, Brauns-Schubert P, Schlicher L, Charvet C (2014) GSK-3 - at the crossroads of cell death and survival. J Cell Sci 127: 1369-1378. https://doi.org/10.1242/jcs.138057

Mazur-Melewska K, Jończyk K, Modlińska-Cwalińska A, Figlerowicz M, Sluzewski W (2014) Visceral larva migrans syndrome: analysis of serum cytokine levels in children with hepatic lesions confirmed in radiological findings. Parasite Immunol 36:668-673. https://doi. org/10.1111/pim.12143

Meevissen MHJ, Driessen NN, Smits HH, Versteegh R, van Vliet SJ, van Kooyk Y, Schramm G, Deelder AM, Haas H, Yazdanbakhsh M, Hokke CH (2012) Specific glycan elements determine differential binding of individual egg glycoproteins of the human parasite Schistosoma mansoni by host C-type lectin receptors. Int J Parasitol 42:269-277. https://doi.org/10.1016/j.ijpara.2012.01.004

Naka T, Nishimoto N, Kishimoto T (2002) The paradigm of IL-6: from basic science to medicine. Arthritis Res 4:233-242. https://doi.org/10.1186/ar565

Okano M, Satoskar AR, Nishizaki K, Abe M, Harn DA (1999) Induction of Th2 responses and IgE is largely due to carbohydrates functioning as adjuvants on Schistosoma mansoni egg antigens. J Immunol 163: $6712-6717$

Page AP, Rudin W, Fluri E, Blaxter ML, Maizels RM (1992) Toxocara canis: a labile antigenic surface coat overlying the epicuticle of infective larvae. Exp Parasitol 75:72-86

Park HJ, Lee SJ, Kim SH, Han J, Bae J, Kim SJ, Park CG, Chun T (2011) IL-10 inhibits the starvation induced autophagy in macrophages via class I phosphatidylinositol 3-kinase (PI3K) pathway. Mol Immunol 48:720-727. https://doi.org/10.1016/j.molimm.2010.10.020

Peon AN, Espinoza-Jimenez A, Terrazas LI (2013) Immunoregulation by Taenia crassiceps and its antigens. Biomed Res Int 2013:498583498513. https://doi.org/10.1155/2013/498583

Pinelli E, Brandes S, Dormans J, Gremmer E, Van Loveren H (2008) Infection with the roundworm Toxocara canis leads to exacerbation of experimental allergic airway inflammation. Clin Exp Allergy 38: 649-658. https://doi.org/10.1111/j.1365-2222.2007.02908.x

Prasanphanich NS, Mickum ML, Heimburg-Molinaro J, Cummings RD (2013) Glycoconjugates in host-helminth interactions. Front Immunol 4:1-22. https://doi.org/10.3389/fimmu.2013.00240

Quan JH, Cha GH, Zhou W, Chu JQ, Nishikawa Y, Lee YH (2013) Involvement of PI 3 kinase/Akt-dependent bad phosphorylation in Toxoplasma gondii-mediated inhibition of host cell apoptosis. Exp Parasitol 133:462-471. https://doi.org/10.1016/j.exppara.2013.01.005

Resende NM, Gazzinelli-Guimarães PH, Barbosa FS, Oliveira LM, Nogueira DS, Gazzinelli-Guimarães AC, Gonçalves MTP, Amorim CCO, Oliveira FMS, Caliari MV, Rachid MA, Volpato GT, Bueno LL, Geiger SM, Fujiwara RT (2015) New insights into the immunopathology of early Toxocara canis infection in mice. Parasit Vectors 8:354. https://doi.org/10.1186/s13071-015-0962-7

Rocher C, Singla DK (2013) SMAD-PI3K-Akt-mTOR pathway mediates BMP-7 polarization of monocytes into M2 macrophages. PLoS One 8:e84009. https://doi.org/10.1371/journal.pone.0084009

Salari S, Seibert T, Chen Y, Brien ERO (2013) Extracellular HSP27 acts as a signaling molecule to activate NF- $\mathrm{K}$ B in macrophages. Cell Stress Chaperones 18:53-63. https://doi.org/10.1007/s12192-012-0356-0

Salminen A, Hyttinen JMT, Kaarniranta K (2011) AMP-activated protein kinase inhibits NF-KB signaling and inflammation: impact on healthspan and lifespan. J Mol Med 89:667-676. https://doi.org/ 10.1007/s00109-011-0748-0

Schabussova I, Amer H, van Die I, Kosma P, Maizels RM (2007) OMethylated glycans from Toxocara are specific targets for antibody binding in human and animal infections. Int J Parasitol 37:97-109. https://doi.org/10.1016/j.jpara.2006.09.006

Shapouri-Moghaddam A, Mohammadian S, Vazini H, Taghadosi M, Esmaeili SA, Mardani F, Seifi B, Mohammadi A, Afshari JT, Sahebkar A (2018) Macrophage plasticity, polarization, and function in health and disease. J Cell Physiol 233:6425-6440. https://doi.org/10.1002/jcp.26429

Silva-Álvarez V, Folle AM, Ramos AL, Kitano ES, Iwai LK, Corraliza I, Córsico B, Ferreira AM (2016) Echinococcus granulosus antigen B binds to monocytes and macrophages modulating cell response to inflammation. Parasit Vectors 9:1-17. https://doi.org/10.1186/ s13071-016-1350-7

Smeenk L, van Heeringen SJ, Koeppel M, Gilbert B, Janssen-Megens E, Stunnenberg HG, Lohrum M (2011) Role of p53 serine 46 in p53 target gene regulation. PLoS One 6:e17574. https://doi.org/10.1371/ journal.pone.0017574

Smith KA, Maizels RM (2014) IL-6 controls susceptibility to helminth infection by impeding Th2 responsiveness and altering the Treg phenotype in vivo. Eur J Immunol 44:150-116. https://doi.org/10. 1002/eji.201343746

Smith HV, Quinn R, Kusel JR, Girdwood RWA (1981) The effect of temperature and antimetabolites on antibody binding to the outer surface of second stage Toxocara canis larvae. Mol Biochem Parasitol 4:183-193

Tawill S, Le Goff L, Ali F, Blaxter M, Allen JE (2004) Both free-living and parasitic nematodes induce a characteristic $\mathrm{Th} 2$ response that is dependent on the presence of intact glycans. Infect Immun 72:398 407. https://doi.org/10.1128/IAI.72.1.398-407.2004

Tsan MF, Gao B (2009) Heat shock proteins and immune system. J Leukoc Biol 85:905-910. https://doi.org/10.1189/jlb.0109005

Van der Kleij D, Latz E, Brouwers JFHM, Kruize YCM, Schmitz M, Kurt-Jones EA, Espevik T, De Jong EC, Kapsenberg ML, Golenbock DT, Tielens AGM, Yazdanbakhsh M (2002) A novel host-parasite lipid cross-talk. Schistosomal lyso-phosphatidylserine activates toll-like receptor 2 and affects immune polarization. J Biol Chem 277:48122-48129. https://doi.org/10.1074/jbc.M206941200

Vergadi E, Ieronymaki E, Lyroni K, Vaporidi K, Tsatsanis C (2017) Akt signaling pathway in macrophage activation and M1/M2 polarization. J Immunol 198:1006-1014. https://doi.org/10.4049/jimmunol.1601515

Voss OH, Batra S, Kolattukudy SJ, Gonzalez-Mejia ME, Smith JB, Doseff AI (2007) Binding of caspase-3 prodomain to heat shock protein 27 regulates monocyte apoptosis by inhibiting caspase-3 proteolytic activation. J Biol Chem 282:25088-25099. https://doi. org/10.1074/jbc.M701740200

Wang MQ, Jiang HJ, Inoue H, Myozaki M, Yamashita U (1995) B cell mitogenic activityof Toxocara canis adult worm antigen. Parasite Immunol 17:609-615

Wen AY, Sakamoto KM, Miller LS (2010) The role of the transcription factor CREB in immune function. J Immunol 185:6413-6419. https://doi.org/10.4049/jimmunol.1001829

Wilson EH, Katz E, Goodridge HS, Harnett MM, Harnett W (2003) In vivo activation of murine peritoneal B1 cells by the filarial nematode phosphorylcholine-containing glycoprotein ES-62. Parasite Immunol 25:463-466. https://doi.org/10.1111/j.1365-3024.2003.00650.x

Zaiss MM, Maslowski KM, Mosconi I, Guenat N, Marsland BJ, Harris NL (2013) IL-1 $\beta$ suppresses innate IL-25 and IL-33 production and maintains helminth chronicity. PLoS Pathog 9:e1003531. https:// doi.org/10.1371/journal.ppat.1003531

Zawistowska-Deniziak A, Basałaj K, Strojny B, Młocicki D (2017) New data on human macrophages polarization by Hymenolepis diminuta tapeworm - an in vitro study. Front Immunol 8:1-15. https://doi. org/10.3389/fimmu.2017.00148

Zizzari IG, Napoletano C, Battisti F, Rahimi H, Caponnetto S, Pierelli L, Nuti M, Rughetti A (2015) MGL receptor and immunity: when the ligand can make the difference. J Immunol Res 450695:1-8. https:// doi.org/10.1155/2015/450695

Publisher's note Springer Nature remains neutral with regard to jurisdictional claims in published maps and institutional affiliations. 